\title{
The Comparative Study of Teacher's Ethics Education in China and the United States
}

\author{
Jie Zeng ${ }^{1, a}$ \\ ${ }^{1}$ Chengdu Normal University, School of Foreign Languages, Wenjiang District of Chengdu, Sichuan \\ Province, China, 611130 \\ aemail,
}

Keywords: Comparative Study, Teacher's Ethics Education, China, the United States

\begin{abstract}
Chinese economic society is in a period of rapid development, science and education as a long-term basic national policy, it is related to the process of modernization of our country. Teachers 'professional ethics are increasingly concerned by the society. Teachers' morality is the basic means of teachers 'professional ethics construction. Teachers' education research is of great significance to improve the education level of teachers in our country. Through the comparative study of Chinese and American morality education, this paper expounds the differences between Chinese and American morality education and analyzes the reasons of difference, with a view to providing reference for strengthening the morality education in our country.
\end{abstract}

\section{Introduction}

Education is the foundation of the country, where teachers are the foundation of education and teachers are the foundation of teachers. Colleges and universities shoulder the training of specialized talents and cultivate the historical mission and responsibility of building socialism successors. Therefore, strengthening the morality education in colleges and universities is one of the important measures to realize the modernization of education in our country. For a long time, the work of moral education in colleges and universities in our country has made some achievements, but with the advent of reform and opening up and the period of social transformation, we have to reflect on the morality and education of colleges and universities in our country. In the existing problems, and continue to explore the new path of development of moral education in colleges and universities in China.

This paper summarizes the history, characteristics and influencing factors of the development of morality and morality education in Chinese and American colleges and universities through the study of the current situation of morality and morality education in Chinese and American colleges and universities, and compares the common and different characteristics of the morality and morality education in Chinese and American colleges and universities.

\section{The Meaning of Teacher's Ethics}

It can be seen that, regardless of ancient and modern, although the definition of teachers is different, the standard is also different, but the moral connotation should include the community, students and teachers themselves to their own requirements. First of all, the connotation of teachers and teachers in the teaching work at the same time assume the responsibility of cultivating civilians for the community; secondly, the teacher needs teachers to use love, sincere, enthusiastic encourage each student, to stimulate the potential of each student, all students grow into talent; Finally, the connotation of teachers asked teachers to continuously improve their professional standards to enhance personal qualities. On the whole, teachers 'professional ethics is the basic moral requirement put forward by the society to the teachers' profession. It is the sum of the more stable moral quality, ideological consciousness and behavioral norms formed by teachers in the practice of education and teaching. 


\section{The Commonality of Teachers' Ethics Education in Chinese and American Colleges and Universities}

The Importance of Teacher Moral Education in Colleges and Universities. China and the United States have different social systems, one is a typical Eastern socialist country, one is the representative of Western capitalist countries both attach great importance to the development of higher education, attention to teachers in the status of higher education development. Teachers have a wealth of knowledge and a good work ethic, can guarantee the quality of higher education, the purpose of moral education is to ensure that team moral and ethical standards of teachers, and both countries have attached great importance moral education

The development of teachers' moral education in colleges and universities is of great significance to the development of higher education. The level of teachers' professional ethics directly determines the quality of higher education and the quality of cultivating talents. The ideological and political moral level of teachers determines the development direction of higher education. Therefore, both countries attach great importance to the impact of teacher professional ethics on the quality of higher education.

The Way of Teacher Moral Education in Colleges and Universities. College ethics education involves a wide range of work content, but also has a variety of ways to build ways. The development of relevant moral education moral education is the basic way of American University, can constrain the behavior of teachers in professional activities through the development of certain norms, the ultimate goal is to improve teachers' professional ethics in order to better serve National nurturing talent.

Chinese teacher morality education in colleges and universities in 2011 issued by the "higher school teachers' professional ethics" as the representative of the standard issue is not long, but the "norm" issued for our country's moral education provides a guide. Chinese "standard" pay more attention to the content requirements for teachers moral level, including the moral requirements of the state, society and all aspects of students to express promote advocacy style-based, therefore, normative and operational constraints on teachers Less than the United States, which is Chinese moral education still need to improve the construction of the place.

The Exemplary Role of College Teachers. Teachers' education is centered around teachers, so both China and the United States attach great importance to the exemplary role of teachers in teacher morality education in colleges and universities. In the United States, the requirements of teachers in colleges and universities, both academic and moral ethics are almost harsh, they believe that teachers let students in thinking to achieve a valuable goal is the most important task in teaching, which requires teachers to set the rich knowledge of the reserves and a high level of moral in one. The level of moral level is an important reference for teachers in the United States to complete a fixed moral task teachers may continue to renew with the school, the stability of teachers and teachers directly linked to exemplary.

\section{The Differences between Teachers' Ethics Education in Chinese and American Colleges and Universities}

The Guiding Ideology of Moral Education in Colleges and Universities. As the world's most influential capitalist system, the idea of guiding the construction of professional ethics in American colleges and universities is always standing on the position of serving the bourgeoisie. The values advocated by the American bourgeoisie emphasize individualism. They think that personal values are higher than social values. Money is a measure of everything and a strict sense of compliance. Therefore, in the construction of professional ethics of teachers in colleges and universities, the United States insists on an individual-centered pragmatism, which always represents the interests of the bourgeoisie and serves the capitalist system.

China is a socialist country with the people's congress system as the fundamental political system, and the socialist core value system guides the work of our society. The socialist nature of our country determines the socialist ideals and the socialist core values which are guided by the Marxist 
theory, and the socialist core values of the 18th National Congress of the Communist Party of China are guided by the ideals and beliefs of socialism. In addition, China is experiencing the baptism of 5,000 years of civilization, experienced a long feudal society, pay attention to the "unified system" culture, emphasizing the overall interests, so the principle of collectivism is one of the principles of moral education in our country.

The Method of Moral Education in Colleges and Universities. As the guiding ideology of teachers and students in China and the United States and the construction of the main body of the differences, therefore, the two countries in the school moral education methods there are some differences. The United States is not a single method for the construction of teachers 'professional ethics, civic and moral education in society in general and religious education is permeated with certain teachers' professional ethics education, which played a significant role in the penetration of the construction of the professional ethics of teachers. This approach avoids the short-term centralized inculcation of moral education, but will be the moral education propaganda into other activities, which to some extent promoted the internalization of moral education. Secondly, the United States attaches great importance to the system construction of moral education in colleges and universities, the system construction mainly from the development of scientific and rational moral education and sound evaluation of the ethics of the two aspects of the mechanism.

China in the "Higher School Teachers Professional Ethics" issued a notice that "to do a good job of" norms "to learn publicity, local schools to organize lectures, seminars, seminars and other forms of learning activities, make full use of Newspapers and television, network and other media platform ", the notification can be a certain extent to reflect the characteristics of Chinese moral education methods: First, focus on the use of a variety of ways to combine the publicity, whether it is newspapers, television traditional media new Era network or micro-blogging, micro-channel new media platforms, all publicity ethics education in higher schools, focus on creating a good atmosphere in the moral education of national scope; second, pay attention to ethics theoretical training of university teachers, It is also one of the characteristics of the pedagogical education method in our country. Through the rotation of the socialist core value system, we will continue to strengthen the theoretical foundation of the moral education in colleges and universities, guide the teachers to establish the correct ideals and aspirations of the profession, and fundamentally protect the teachers' road ahead.

System Construction of Teacher Morality Education in Colleges and Universities. American colleges and universities "dual management system". American colleges and universities "dual management system" refers to the United States colleges and universities by the federal government and the state government management. From the previous study of the status quo of American colleges and universities can be seen from the national level, in the system construction of American colleges and universities to establish a strict teacher hiring, evaluation mechanism and a strong legal security system. At the local level, the American university management system and the political management system are consistent and the states have their own educational management authority.

\section{The Suggestion of Comparative Study of Chinese and American Ethics Education on the Development of Moral Education in Colleges and Universities in China}

Focus on the Construction of Teachers. College teachers are the professional knowledge, the managers of student behavior, the promoters of student growth, and the multiple roles in the university. This requires that teachers in colleges and universities must have high comprehensive quality and focus on good ideological and moral accomplishment The A teacher with a high ideological and moral quality can usually use a strong sense of self-moral restraint to guide the adjustment of all aspects of teacher work, good ideological and moral qualities can make teachers more consciously abide by the teacher's professional ethics, perform teacher duties, introspection Teacher behavior to form a good moral qualification.

Improve the Moral Education System. In the United States, colleges and universities have the moral requirements of teachers, but the moral education is mainly embodied in the binding function, 
and our moral education is mostly moral ideal, with the incentive function as the focus, easily lead to the implementation of moral education and supervision mechanism is not perfect. As a complete and reasonable moral education, moral ideals, moral principles and moral norms are complementary, which in turn moral norms, moral education, incentive function, guiding function and constraint function is indispensable, and should be constraint-based. Therefore, from the actual situation, the system of moral education should start from the professional characteristics of teachers, the specific formulation of moral norms, the establishment of national education and supervision, the main body of teachers similar to the implementation of professional ethics and supervision institutions to play the moral education of the binding function.

Integrate All Parties to Promote the Development of Moral Education. University is the cradle of personnel training, the purpose of moral education in colleges and universities is to enhance the professional quality of teachers, better nurturing talent. All the principles and policies of the university should serve and obey the goal of nurturing talents and meet the requirements of students in many aspects. Insist for all students, for all the students to explore and play the potential of students for students to create the conditions for comprehensive and free development. Therefore, we should pay attention to the participation of students in the education of moral education in the process of moral education in colleges and universities. It can be interviewed, questionnaires, etc. to understand the students for the degree of satisfaction with the moral education; can establish a "student teacher education feedback letterbox" to the needs of students in a timely manner to the school, while paying attention to the students on the moral education related recommendations.

\section{Conclusion}

In the course of higher education reform and development, we cannot "shut up the door to engage in development", and insist on independent and independent exploration, but also know how to learn from the study of the development of higher education in the process of higher education reform and development. And constantly improve the level of moral education in colleges and universities in China to promote the development of higher education for the country to cultivate more talent.

\section{Acknowledgements}

Fund Project: This article is the Sichuan Provincial Education Department 2015 Annual Humanities and Social Science Research Project, the project number is 15 SB0243

\section{References}

[1] Yan - long, Rong Jun - shi. Discussion on the educational mechanism of young teachers' morality in colleges and universities under the new situation[J]. Journal of Anhui University of Technology. 2014(05)

[2] Li Min, Yu Huizhen. Contemporary Chinese and American primary and secondary school teachers professional ethics comparison and reflection [J]. Teaching and management. 2012 (06)

[3] Lu Pin, Li Xiaoyue, Liu Wanguang. On explicit education and recessive (Social Science Edition) Journal of Taiyuan Urban Vocational College[J]. Journal of Taiyuan Urban Vocational College"2010(08)

[4] Chen Ruili. On the "people-oriented" educational philosophy under the college student management work [J]. Journal of Jiangsu Vocational and Technical College of Economics and Trade. 2007(02)

[5] SUN Jin, LU Li-song, SONG Xiao-ping.Comparison of Moral Education in Contemporary Chinese and American Universities[J]. Journal of China Youth College for Political Sciences. 2006 